b) Objawem izolacji Komunii św. od Mszy św. było przyjmowanie Komunii św. przed Mszą lub po niej bez istotnej potrzeby, a nawet niekiedy w oderwaniu od Mszy św. Stąd traktowanie Komunii św. jako oddzielnego nabożeństwa, coś w rodzaju praktyki pobożnej. Do dzisiaj przetrwał jeszcze jeden objaw izolacji Komunii św. od Mszy św., a mianowicie podawanie Komunii św. z komunikantów znajdujących się w tabernakulum. Taka praktyka bardzo przeszkadza wiernym w zrozumieniu prawdy, że Komunia św. należy do Mszy św., że jest jej owocem, z którego trzeba skorzystać, a ten, który tego nie czyni, nie uczestniczy w sposób pełny we Mszy św.

Liturgia musi być przeżywana w naszych parafiach jako siła tworząca wspólnotę z Bogiem i z braćmi, a dla osiągnięcia takiego celu warto zdobyć się na najwyższy wysiłek.

Przemyśl

KS. WEADYSEAW GEOWA

\author{
Ks. Roman Michalek $†$
}

\title{
ZADANIA DIECEZJALNEJ KOMISJI DO SPRAW LITURGII W ŚWIETLE DOKUMENTÓW KOSCIOKA
}

\section{WSTEP}

$\mathrm{Z}$ całą pewnością celem niniejszego opracowania jest zwykłe przypomnienie tych wskazań zawartych w dokumentach Kościoła, które mówią o zadaniach Diecezjalnych Komisji ds. Liturgii oraz porównanie i skomentowanie odnośnych dyrektyw. Nie można bowiem mówić o zapoznaniu z odnośnymi źródłami, gdyż członkowie Komisji orientują się w spoczywających na Nich zadaniach. Drugim zaś i nie mniej ważnym celem tego opracowania jest wprowadzenie do dyskusyjnej i twórczej wymiany myśli.

Przez określenie „dokumenty Kościoła” rozumiemy dokumenty Kościoła powszechnego i Kościołów partykularnych. Dlatego przy opracowywaniu tego elaboratu korzystano z następujących źródeł i literatury:

\section{a) odnośnie Kościoła Powszechnego}

1. Motu Proprio De musica sacra św. Piusa X z 22 XI 1903.

2. Okólnik Sekretariatu Stanu w sprawie sztuki sakralnej z 1 IX 1924.

3. Encyklika o liturgii Mediator Dei Piusa XII z 20 XI 1947. 
4. Instrukcja Kongregacji Obrzędów (KO) o muzyce sakralnej i liturgii z 3 IX 1958.

5. Soborowa Konstytucja o Liturgii z 4 XII 1963 (KL):

6. Motu Proprio Sacram Liturgiam z 25 I 1964.

7. Pierwsza Instrukcja (KO) o należytym realizowaniu KL - Inter Oecumenici z 26 IX 1964.

8. Drugi List Przewodniczącego Rady dla realizowania KL (kardynała Lercaro) do Przewodniczących Konferencji Biskupich w sprawie wprowadzania w życie reformy liturgii z 25 I 1966.

9. Instrukcja (KO i Rady dla realizowania $\mathrm{KL}$ ) o muzyce w liturgii Musicam sacram z 5 III 1967.

10. Instrukcja $(\mathrm{KO})$ o uproszczeniu obrzędów i odznak biskupich z 21 VI 1968.

11. Wprowadzenie Ogólne do Mszału Rzymskiego z 6 IV 1969.

12. Instrukcja (Kongregacji Kultu Bożego) o stopniowym realizowaniu Konstytucji Apostolskiej Missale Romanum z 20 X 1969.

13. Trzecia Instrukcja (Kongregacji Kultu B.) o należytym realizowaniu KL - Liturgicae instaurationes z 5 IX 1970.

14. Okólnik (Kongregacji Duchowieństwa) w sprawie troski o zachowanie historyczno-artystycznego dziedzictwa Kościoła z 11. IV 1971.

15. Dyrektorium (Kongregacji Biskupów) o duszpasterskiej posłudze Biskupów z 22 II 1973.

16. Liturgia sakramentu pojednania (Ordo Paenitentiae) z 2 XII 1973.

\section{b) Odnośnie Kościoła w Polscé}

1. Wytyczne prac Diecezjalnej Komisji ds. Liturgii, Muzyki i Spiewu Kościelnego (w Częstochowie) z 31 VIII 1961. ${ }^{1}$

2. Regulamin Archidiecezjalnej Komisji Liturgicznej w Warszawie z 6 III $1965 .^{2}$

3. Informacje o funkcjach i zadaniach Archidiecezjalnej Komisji Liturgicznej w Warszawie z $18 \mathrm{~V} 1965 .^{3}$

4. Powołanie Diecezjalnej Komisji Liturgicznej w Gdańsku, 8 IX $1965 .{ }^{4}$

5. Dekret o ustanowieniu Diecezjalnej Komisji Liturgicznej w Gorzowie z 29 XI 1965.5

6. Statut Diecezjalnej Komisji Liturgicznej, przyjęty przez Komisję Liturgiczną Episkopatu Polski 4 I 1968. ${ }^{6}$

1 T. Pier onek, Prawodawstwo Kościoła w Polsce 1961-1970, t. II; Ustawodawstwo diecezjalne, Warszawa 1974, zesz. 1, s. 99 n.

2 T. Pieron e k, dz. cyt., zesz. 4, s. $105-107$.

3 T. Pieronek, dz. cyt., zesz. 4, s. 108 n.

4 T. Pi e r on ek, dz. cyt., zesz. 1 , s. $180 \mathrm{n}$.

5 T. Pieronek, dz. cyt., zesz. 2, s. 52.

6 Statuty Archidiecezjalnego Synodu Poznańskiego 1968, Poznań 1972, 
7. Regulamin dekanalnych referentów liturgicznych (Archidiecezji Poznańskiej) z 28 I 1970.7

8. Regulamin Komisji Episkopatu Polski ds. Liturgii i Duszpasterstwa Liturgicznego z 4 X 1978 (maszynopis).

\section{c) Odnośnie literatury}

1. Sztafrowski E., Prawo kanoniczne $w$ okresie odnowy soborowej; t. I, W-wa 1976 (s. 375-379).

2. Sztafrowski E., Wspótpracownicy Biskupa diecezjalnego $w$ pasterskim postugiwaniu, W-wa 1977 (s. 120-124. 127. 133).

3. Tschuschke M., Rola dekanalnych referentów liturgicznych na podstawie regulaminu, „Miesięcznik Kościelny Archidiecezji Poznańskiej" 21 (1970) 65-69.

\section{KROTKA HISTORIA I CHARAKTER DIECEZJALNEJ KOMISJI D. S. LITURGII}

1. Pierwszym dokumentem Kościoła powszechnego, który zaleca, by w każdej diecezji powstał organ dla popierania apostolstwa liturgicznego, jest dopiero encyklika Mediator Dei z r. 1947. Znacznie, bo 44 lata wcześniej, w r. 1903 pap. św. Pius X w motu proprio Tra le sollecitudini ( $\mathrm{nr}$ 24) wyraził życzenie, aby w każdej diecezji ustanowiono organ dla popierania muzyki sakralnej, a 23 lata wcześniej, w roku 1924 Okólnik Sekretariatu Stanu polecił ustanowić diecezjalny organ dla popierania sztuki sakralnej. Jest rzeczą znamienną. że tego rodzaju organy istniały już przedtem w niektórych krajach, zwłaszcza w Belgii i $\mathrm{z}$ wielkim pożytkiem ściśle współpracowały $\mathrm{z}$ hierarchią nad rozwojem ruchu liturgicznego ${ }^{8}$. Najbardziej interesujące nas $w$ t $\in \mathrm{j}$ chwili zdanie ze wspomnianej encykliki warto przypomnieć in extenso: „Pragniemy (mówi papież), aby w poszczególnych diecezjach byly ustanowione rady dla popierania apostolstwa liturgicznego, jak już istnieją dla muzyki kościelnej i ochrony sztuki, aby dzięki waszej (Biskupów) pieczy wszystko odbywało się w myśl rozporządzeń Stolicy Apostolskiej".

2. Warto też zwrócić uwagę na określenie omawianego organu diecezjalnego mianem „Rada (Consilium)". Tej samej nazwy używa jeszcze w styczniu 1964 r. motu proprio Sacram Liturgiam (nr II). Inne natomiast odnośne dokumenty, mianowicie: wpierw Instrukcja

S. 359-364 oraz: „Częstochowskie Wiadomości Diecezjalne” 8-10 (1970) 232-236 i "Wiadomości Urzędowe Kurii Biskupiej Śląska Opolskiego" 4 (1968) 93-96 (por. T. Pieronek, dz. cyt., zesz. 1, s. 128-133 i zesz. 2, s. $286-291)$.

7 ,Miesięcznik Kośçielny Archidiecezji Poznańskiej” 21 (1970) 58-60.

8 Piusa XII encyklika Mediator Dei, Kielce 1948, s. 19. 
o muzyce sakralnej i liturgii z r. 1958 (nr 118), a później soborowa Konstytucja o Liturgii (z r. 1963, nr $45 \mathrm{n}$. oraz 126), pierwsza Instrukcja o należytym realizowaniu tej Konstytucji Inter Oecumenici. ( $\mathrm{z}$ września $1964, \mathrm{nr} 39$ i 47 ) oraz wszystkie następne dokumenty zawsze używają określenia „Komisja (Commissio)”. Już z samych obu tych określeń jasno wynika, jaki charakter ma omawiany organ diecezjalny. Ma on mianowicie charakter doradczy (Rada) i wykonawczy (Komisja), a nie decydujący, ustawodawczy. Przykładem tego może być wyraźne i do dziś obowiązujące postanowienie Stolicy Apostolskiej, że o ustawieniu tabernakulum poza ołtarzem może zadecydować tylko Ordynariusz miejsca, a nie np. Diecezjalna Komisja Liturgiczna ${ }^{9}$.

\section{ZADANIA OGÓLNE}

Zanim przejdziemy do właściwego tematu, wypada jeszcze przytoczyć to, co polski Statut Diecezjalnej Komisji Liturgicznej nakłada na każdego jej członka jako naczelny obowiązek, bez wypełnienia którego Komisja nie może realizować swych zadań. Tym podstawowym obowiązkiem jest, w miarę możności, dokładna znajomość liturgiki w jej wieloaspektowym, wszechstronnym ujęciu, a więc biblijnym, dogmatycznym, historycznym, pastoralnym, ascetyczno-mistycznym i prawnym. Ponieważ zaś liturgia nie jest statyczna, ale dynamiczna, dlatego wiedzę o niej stale trzeba pogłębiać, poszerzać i aktualizować, studiując nowe dokumenty i odnośne wyjaśnienia oraz ukazującą się literaturę liturgiczną.

Rozpatrując w świetle dokumentów Kościoła zadania Diecezjalnej Komisji ds. Liturgii można wśród nich rozróżnić zadania ogólne i szczegółowe. Zadania ogólne wymienia cyt. Instrukcja Inter Oecumenici w nr. 47. Przypomnijmy je nie dosłownie, lecz opisowo:

Pierwsze zadanie ogólne: członkowie Komisji mają poznać aktualny stan działalności duszpastersko-liturgicznej na terenie swej die-cezji.

Drugie zadanie ogólne: członkowie mają sami wprowadzać w życie postanowienia Stolicy Apostolskiej, Konferencji Episkopatu i Ordynariusza miejsca w zakresie liturgii, czuwać, by inni te postanowienia realizowali oraz interesować się studiami i inicjatywami dokonywanymi w tej dziedzinie w innych diecezjach.

Trzecie zadanie: Komisja ma sugerować i popierać różne praktyczne inicjatywy, które mogą się przyczynić do rozwoju liturgii oraz ma w tym kierunku pomagać kapłanom pracującym w duszpasterstwie.

9 Drugi List Rady dla realizowanía KL skierowany do Przewodniczących Konferencji-Biskupów z 25 I 1966, nr 6; por. też: I Instrukcja o należytym realizowaniu KL Inter Oecumenici z 26 IX 1964, nr 95; Instrukcja Eucharisticum mysterium z $25 \mathrm{~V}$ 1967, nr 54; De sacra communione et de cultu mysterii eucharistici extra Missam z 21 VI 1973, nr 10. 
Czwarte zadanie ogólne: podsuwać odpowiednie i urzeczywistniane etapami plany pracy duszpastersko-liturgicznej w poszczególnych kościołach i parafiach oraz na terenie diecezji; doradzać albo sprowadzać odpowiednich ludzi, którzy mogą pomagać kapłanom w dziedzinie liturgii; proponować odpowiednie środki i pomoce.

I wreszcie piąte zadanie ogólne: Komisja ma usilnie zabiegace, aby inicjatywy podejmowane dla pogłębienia życia liturgicznego pomyśslnie się rozwijały, przy wzajemnej i zgodnej współpracy z innymi organami, które pracują na terenie diecezji w dziedzinie biblijnej, katechetycznej, duszpasterskiej, muzyki i sztuki kościelnej oraz przy współpracy z wszelkiego rodzaju religijnymi stowarzyszeniami świeckimi.

Oczywiście dla spełnienia tych zadań Diecezjalna Komisja Liturgiczna powinna odbywać posiedzenia, wg Instrukcji o muzyce sakralnej i liturgii z r. 1958 zależnie od potrzeb, a wg polskiego Statutu -cztery razy w roku, w razie zaś konieczności częściej.

\section{ZADANIA SZCZEGÓEOWE}

Przy dokładnej analizie interesujących nas powszechnych i partykularnych dokumentów można wyodrębnić zadania i obowiązki Diecezjalnej Komisji Liturgicznej w stosunku do: Komisji Liturgicznej Episkopatu Polski, do Ordynariusza miejsca i Kurii Diecezjalnej, do innych organów diecezji oraz do kapłanów i ludu Bożego.

\section{a) Zadania $w$ odniesieniu do Komisji Liturgicznej Episkopatu}

Polski Statut postanawia, że Komisja Diecezjalna powinna utrzymywać łączność z Komisją Episkopatu oraz - w miarę potrzeby nadsyłać jej swoje wnioski. Oczywiście oprócz kierowania wniosków nieraz wypadnie zwrócić się z zapytaniem o wyjaśnienie poważniejszej wątpliwości, jeśli je może rozstrzygnąć albo sama Komisja Episkopatu albo Konferencja Biskupów (bez konieczności odnoszenia się do Stolicy Apostolskiej). Głównym jednak zadaniem w tym pionie jest wykonywanie. pewnych prac zleconych przez Komisję Episkopatu (zwykle za pośrednictwem Ordynariusza miejsca). Prace te obejmują np. przygotowanie polskich przekładów nowych ksiąg i dokumentów liturgicznych albo wydanie opinii o projektach takich przekładów. Nie ulega wątpliwości, że od rzetelnego i terminowego wykonania zleceń w dużym stopniu zaleźy pomyślne realizowanie w naszym kraju soborowej odnowy liturgicznej.

\section{b) Zadania wobec Ordynariusza miejsca i Kurii Diecezjalnej}

Ponieważ Diecezjalna Komisja ds. Liturgii jest przede wszystkim organem doradczym i wykonawczym Biskupa i jego Kurii, dlatego 
w tym pionie ma najwięcej zadań. Wymienimy i omówimy je w dziesięciu punktach.

1. Ujmując rzecz całościowo Komisja pomaga Ordynariuszowi miej-sça i Kurii Diecezjalnej w kierowaniu życiem liturgicznym diecezji oraz w formacji liturgicznej kapłanów i ludu Bożego. Tak postanawia Dyrektorium o duszpasterskiej posłudze Biskupów z 22 II 1973 (w nr 82) oraz nasz polski Statut ${ }^{10}$.

2. Nieco konkretniej ujmuje zadania III Instrukcja o należytym realizowaniu KL Liturgicae instaurationes z 5 IX 1970, która we wstępie postanawia, że Komisja pomaga Biskupowi:

a) poznać stan życia liturgicznego w diecezji, oraz

b) kierować tym życiem przez:

- odpowiednie zarządzenia,

- przez troskę, by dzieło odnowy było realizowane zgodnie z przepisami

- i przez wykorzystywanie uprawnień, jakie dają nowe obrzędy.

3. Przechodząc do konkretów bardziej szczegółowych wypada wymienić wpierw wykonywanie różnych prac z dziedziny liturgicznej zleconych przez Ordynariusza miejsca i jego Kurię ${ }^{10}$. Chodzi tu np. o przygotowanie różnych potrzebnych opracowań, służenie radą, wydawanie opinii (o czym wyraźnie mówi polski Statut).

4. Bardzo dużą pomocą dla Władzy Duchownej jest przygotowanie projektów liturgicznych dekretów, instrukcji dla diecezji oraz odpowiedzi na wątpliwości przedstawione przez kapłanów i wiernych.

5. Jeśli rozstrzygnięcie wątpliwości przekracza kompetencje miejscowej Władzy Duchownej, a nawet Konferencji Episkopatu Polski, wtedy trzeba - oczywiście po odpowiednim zredagowaniu - przesłać je za pośrednictwem Ordynariusza miejsca do Kongregacji Sakramentów i Kultu Bożego.

6. Nie tylko Diecezjalna Komisja ds. Sztuki Sakralnej (która miewa i inne nazwy, np. artystyczna i architektoniczna, artystyczno-budowlana, artystyczno-konserwatorska, budowy i konserwacji kościołów), lecz także Komisja ds. Liturgii ma, a przynajmniej mieć powinna, w odniesieniu do sztuki sakralnej wielkie pole działania; mówimy: powinna mieć, bo doświadczenie uczy, że niestety dość często jest po prostu pomijana. Jej rolę w tej dziedzinie określa ogólnie soborowa KL, która w art. 126 postanawia, że przed ocenieniem przez Ordyna.riusza miejsca dzieł sztuki ma - jeśli za tym przemawiają okoliczności - wydać o nich opinię także Komisja Liturgiczna ${ }^{10}$.

Dokładniej określają jej zadania w tych sprawach inne dokumenty, np. Wstęp Ogólny do Mszału Rzymskiego (w $n r$ 256). Poleca on mianowicie, by Komisja Liturgiczna sł̉użyła radą i pomocą Ordynariuszowi miejsca przy: ustaleniu przepisów, badaniu i zatwierdzaniu 
projektów oraz rozstrzyganiu ważniejszych spraw dotyczących budowy, urządzania i odnawiania miejsc sakralnych ${ }^{10}$.

$\mathrm{Z}$ kolei już wyżej wymieniona Instrukcja Liturgicae instaurationes (z r. 1970) w nr 10 ustaliła, że Komisja powinna służyć Biskupowi radą i pomocą przy: zachowywaniu starych zabytków sztuki kościelnej, dostosowywaniu ich - jeśli to wskazane i możliwe - do nowych wymagań oraz przy badaniu i zatwierdzaniu projektów sakralnych urządzeń wpierw tymczasowych, a potem stałych.

Dalszy dokument: Okólnik Kongregacji Duchowieństwa w sprawie troski o zachowanie historyczno-artystycznego dziedzictwa Kościoia (z 11 IV 1971) w nr 4 postanawia, że Komisja Liturgiczna opracowuje dla Biskupa opinię o wszelkich zmianach $w$ miejscach świętych dokonywanych w związku $\mathrm{z}$ odnową liturgiczną (przeprowadzanych oczywiście ostrożnie i zgodnie $\mathrm{z}$ jej zasadami). Według tegoż Okólnika (nr 7) przy przesyłaniu przez Biskupa do Stolicy Apostolskiej prośby o zezwolenie na sprzedaż kosztowności kościelnych (zwłaszcza wotów) trzeba obowiązkowo dołączyć opinię Komisji Liturgicznej. Bez jej opinii nie można też usunąć już istniejącego baldachimu nad katedrą biskupią. Znana jest zasada, której w tym przypadku trzeba się trzymać: baldachim zostawia się tylko wtedy, jeśli przedstawia on wartościowsze dzieło sztuki, nowych zaś zakładać nie wolno (Instrukcja Pontificales ritus o uproszczeniu obrzędów i odznak biskupich z 21 VI 1968, nr 11).

Cennym dopełnieniem działalności na polu sztuki sakralnej jest pomoc w organizowaniu wystaw szat, naczyń i innych sprzętów liturgicznych, o czym wyraźnie wspomina nasz polski Statut.

7. Komisja Liturgiczna najlepiej zespołowo, a przynajmniej w osobach poszczególnych swych członków (zwłaszcza przewodniczącego, sekretarza czy kurialnego referenta ds. liturgicznych, który powinien być jej członkiem), ma czuwać nad tym, by w urzędowym miesięczni$\mathrm{ku}$ diecezjalnym były publikowane - w miarę możności na bieżąco najnowsze dokumenty, wyjaśnienia i fachowe artykuły liturgiczne (por. cyt. Statut). Bez uprzystępnienia bowiem tych źródeł i literatury nie ma mowy o prawdziwej odnowie liturgii.

8. Duże pole działania otwiera się przed diecezjalną Komisją Liturgiczną, gdy chodzi o służenie pomocą Włady Duchownej (i braciom kapłanom) przez wskazywanie lub opracowywanie materiałów używanych w liturgii. Do materiałów tych należą schematy oraz teksty. nabożeństw liturgicznych i pozaliturgicznych (por. cyt. Statut). Wśród nabożeństw liturgicznych, które Komisja powinna w ten sposób przygotować, dokumenty wymieniają przykładowo: nabożeństwa słowa Bożego (Instr. Inter Oecumenici nr 39) i nabożeństwa pokutne (Orỉo Paenitentiae, Appendix II, nr 2). Dostarczane zaś teksty to przede wszystkim wprowadzenia, zachęty (invitationes seu monitiones), wzory trzeciego aktu pokuty i Modlitwy Powszechnej, komentarze, katechezy i homilie. 
Wygłaszanie odpowiednich katechez liturgicznych ma - jak wiemy - duże znaczenie, głównie (ale nie wyłącznie) przed wprowadzeniem w życie nowych obrzędów liturgicznych, by kapłani i wierni lepiej mogli je rozumieć i wniknąć w ich ducha (por. Instrukcja o stopniowym wprowadzaniu w życie Konstytucji Apost. Missale Romanum, 20 X 1969, $\mathrm{nr} 6$ ).

Specjalną uwagę trzeba zwrócić na Modlitwę Powszechną. Aby uniknąc dość poważnych niestosowności, które niestety czasem się zdarzają, jest rzeczą niedopuszczalną, by $\mathrm{np}$. Kuria rozsyłała formularze tej Modlitwy bez zaopiniowania ich przez diecezjalną Komisję Liturgiczną. Prawda, że według aktualnie obowiązującego prawodawstwa tylko zakończenie (oratio conclusiva) wymaga aprobaty Ordynariusza (De oratione communi seu fidelium, 1966, $\mathrm{nr}$ 18); sformułowanie zaś wstępu leży w kompetencji celebransa, a sformułowąnie poszczególnych intencji - w gestii uczestników danej liturgii. Muszą oni jednak pamiętać, że: są cztery serie próśb, że - jeśli za tym przemawiają okoliczności - kolejność poszczególnych serii można zmienić, że prośby o zbliżonej treści trzeba dołączać do danej serii (a nie mieszać ich), że $\mathrm{w}$ niedziele $\mathrm{i}$ święta w zasadzie może być razem najwięcej sześć próśb oraz że nie wolno ich improwizować, lecz trzeba je uprzednio przygotować na piśmie (cyt. Instr. Liturgicae instaurationes, $\mathrm{nr} 3 \mathrm{~g}$ ).

9. Do zadań Komisji Liturgicznej wobec Ordynariusza miejsca i Kurii diecezjalnej należy też współudział w organizowaniu przynajmniej raz w roku (a w razie potrzeby częściej) odprawy dekanalnych referentów liturgicznych oraz w organizowaniu kursów liturgicznych dla ogółu duchowieństwa (por. cyt. Statut), urządzanych obowiązkowo przynajmniej przed wprowadzeniem w życie nowych ksiąg liturgicznych.

10. Jest też rzeczą nieodzowną, by co najmniej jeden z przedstawicieli Komisji brał udział w dorocznej kongregacji księży dziekanów oraz w ogólnych kursach duszpasterskich i w rejonowych konferencjach duchowieństwa. Podczas tych bowiem spotkań nie rzadko padają w dyskusji czy w wolnych głosach pytania dotyczące liturgii, na które $w$ pierwszym rzędzie powinien dać odpowiedź właśnie reprezentant Komisji.

c) Zadania $w$ stosunku do innych organów diecezjalnych

Dokumenty kościelne kładą duży nacisk na współpracę $\mathrm{z}$ innymt organami diecezjalnymi. I tak np.:

1. Instrukcja Musicam sacram (z 5 III 1967, w nr 68) i polski Statut wyraźnie nakazują współdziałanie z Komisją ds. Muzyki Sakralnej. Soborowa Konstytucja o Liturgii w art. 46 rozszerza konieczność tej współpracy także na Komisję ds. Sztuki Sakralnej, a Instrukcja 
- Muzyce Sakralnej i Liturgii z r. 1958 w nr 118 określa rzecz następująco: jest wskazane, by te trzy Komisje czasem zbierały się razem oraz razem omawiały i rozwiązywały wspólne zadania.

2. Niektóre dokumenty idą dalej i stwierdzają, że czasem w jakiejś diecezji może być celowe, pożyteczne i wskazane, by dla ułatwienia pracy trzy Komisje ds. Liturgii, ds. Muzyki i ds. Sztuki Sakralnej złączyły się w jedną (KL, art. 46; M. Pr. Sacram Liturgiain z 25 I 1964, p. II; cyt. Instr. Musicam sacram z r. 1967, nr 68). W Polsce w jednej điecezji jest jedna wspólna Komisja ds. Liturgii, Muzyki i Sztuki, a w trzech diecezjach jest wspólna Komisja ds. Liturgii i Muzyki Sakralnej.

3. $\mathrm{Za}$ pośrednictwem odnośnego organu kościelnego (np. specjalnego referenta) Diecezjalna Komisja Liturgiczna ma obowiązek czuwać nađ̆ formacją liturgiczną służby ołtarza.

4. Ponieważ dużo uwagi trzeba poświęcić liturgicznemu wychowaniu dzieci i młodzieży, zwłaszcza w ramach katechizacji wszystkich stopni, dlatego konieczna jest stała i rozległa współpraca z kurialnym Wydziałem Katechetycznym ${ }^{10}$.

5. W dobie posoborowej najważniejszy w Kurii jest Wydział Duszpasterski. Dlatego nie należy się dziwić, że polski Statut Diecezjalnych Komisji Liturgicznych do współdziałania z tym Wydziałem przywiązuje bardzo dużą wagę.

6. Przedstawiciele Kurii często wchodzą w skład Kapituły Katedralnej. Ścisłe i konstruktywne kontakty z Kapitułą są bardzo konieczne, bo nabożeństwa katedralne powinny być wzorem dla całej diecezji, a w bardzo dużym stopniu może i powinna do tego się przyczynić właśnie Komisja Liturgiczna:

7. I wreszcie Seminarium Duchowne. Nie może być mowy o prawdziwej odnowie liturgicznej w diecezji, jeśli Komisja nie będzie skutecznie wplywała na wszechstronne liturgiczne wychowanie alumnów, przyszłych duszpasterzy ${ }^{10}$.

\section{d) Zadania w stosunku do kapłanów i wiernych}

1. Naczelnym zadaniem Diecezjalnej Komisji Liturgicznej w odniesieniu do kapłanów i wiernych jest - przy pomocy wszelkich dostępnych środków - liturgiczne ich wychowanie (por. polski Statut) oraz wyrobienie w kapłanach większego zrozumienia dla roli, jaką liturgia spełnia w duszpasterstwie ${ }^{11}$.

10 Por. cyt. Regulamin Archidiecezjalnej Komisji Liturgicznej w Warszawie.

${ }_{11}$ Por. cyt. Wytyczne prac Diecezjalnej Komisji ds. Liturgii, Muzyki i S̉piewu Kościelnego (Częstochowa) oraz cyt. Regulamin Archidiecezjalnej Komisji Liturgicznej w Warszawie. 
2. Przy projektowaniu, budowaniu, urządzaniu i odnawianiu kościołów zainteresowanym duszpasterzom Komisja ds. Liturgii powinna służyć fachowymi radami (IGMR nr 256).

3. Nie wystarcza jednak poprzestać na radach: trzeba też czuwaé, by urządzenie świątyń i odprawianie nabożeństw odpowiadało duchowi i przepisom soborowej odnowy liturgicznej. Nie tyle Komisja jako całość, ile raczej poszczególni jej członkowie mogą i powinni na tym odcinku spełniać dzieło apostolatu liturgicznego, zwłaszcza wtedy, gdy podczas bytności w terenie zauważą jakieś niestosowności. Życzliwa rada, a nawet uwaga, byle taktowna, a tym więcej serdeczna, działa skuteczniej, niż niejedno urzędowe zarządzenie odgórne. $\mathrm{Na}$ podstawie wieloletniej praktyki można przytoczyć przykłady pewnych niedociągnięć w urządzeniu niektórych świątyń, niedociągnięć, na które trzeba reagować przypominaniem i uzasadnianiem odnośnych przepisów:

a) Ołtarz główny powinien być stały (IGMR nr 262). Ponieważ zaś jest miejscem składania Najśw. Ofiary (stołem eucharystycznym), używane do Mszy cum populo paramenty znajdują się - poza Liturgią Eucharystyczną (i ewentualnie obrzędami zakończenia) - na kredensie.

b) Kielich jest obowiązkowo przykryty wêlonem, który jednak zawsze może być biały (IGMR, nr 8.0 c oraz 138; „Notitiae” 14 (1978) 594). Używanie więc welonu kielichowego bynajmniej nie zostało zniesione i nadal obowiązuje. Zniesiono natomiast używanie bursy kielichowej (a używanie palki uzależniono od okoliczności).

c) Ambona (stół słowa Bożego) powinna byč stała. Nie może więc nią być zwykły, przenośny pulpit (IGMR nr 272). Powinna też być jedna, dla zaznaczenia jedności słowa Bożego ${ }^{12}$ oraz dla nawiązania do tradycji wcześniejszej niż stosowanịe dwóch ambon. ${ }^{13}$. Instrukcja Inter Oecumenici dopuszczała wprawdzie dwie ambony. Było to jednak postanowienie przejściowe. Wszystkie późniejsze dokumenty liturgiczne (od r. 1966 aż do najnowszych) mówią zawsze o jednej ambonie. Jeśli w nawie kościoła jest ambona zabytkowa, nie trzeba jej znosić (po ustawieniu nowej w prezbiterium); z zabytkowej można korzystać w duże uroczystości, ale :wtedy głosi się z niej nie tylko hómilię, lecz także lekcje i ewangelię. Jeśli zaś dawna ambona jest położona tuż przy prezbiterium, należy $\mathrm{z}$ niej korzystać nawet na co dzień, a nie ustawiać nowej (w pobliżu ołtarza).

d) Jeśli w obrębie prezbiterium już jest jeden widoczny krzyż, nie wolno stawiać drugiego.

12 A. Pistoia, L'ambiente della celebrazione Eucaristica (Komentarz do Wprowadzenia Ogólnego do Mszału Rz. (IGMR, nr 253-312); „Ephemerides Liturgicae" (= EL) 83 (1969) 416.

13 C. Braga, Commentarium in Instructionem "Inter Oecumenici" EL 78 (1964) 505 . 
e) W prezbiterium każdego domu Bożego muszą być przynajmniej cztery świece ołtarzowe, potrzebne do wystawienia Najśw. Sakramentu w monstrancji ${ }^{14}$. Do Mszy św. potrzeba albo dwóch, albo czterech, albo sześciu świec (a nie trzech, pięciu, ośmiu itd.); siedem natomiast gdy odprawia Biskup rezydencjalny ${ }^{15}$, lub na mocy polskiego zwyczaju - gdy odprawia się Roraty.

f) Humerał nie obowiązuje tylko wtedy, gdy alba jest tak uszyta, że odkrywa kołnierz (IGMR nr 81 i 298).

g) Wszyscy usługujący w prezbiterium ${ }^{16}$ nie wyłączając lektora obowiązkowo mają na sobie przynajmniej komżę, diakon zaś przynajmniej albę i stułę.

h) Celebrans nie idzie do oltarza w birecie i nigdy nie zanosi ani nie odnosi kielicha, bo nie jest portatorem; czyni to usługujący.

Dość często można też zauważyć następujące braki przy sprawowaniu liturgii:

a) stosowanie tylko pierwszej formuły wstępnego pozdrowienia mszalnego, aktu pokuty i aklamacji po przeistoczeniu;

b) rzadkie stosowanie aspersji i odprawianie Nieszporów;

c) rzadkie przestrzeganie prawdziwego milczenia po „Módlmy się”, po czytaniach, a nawet po homilii;

d) niewyraźne śpiewanie (zwłaszcza przez organistę) psalmu responsoryjnego i wiersza przed ewangelią oraz skracanie tego psalmu;

e) zastępowanie części między czytaniami przez pieśń;

f) bezpośrednie przygotowanie ołtarza już pod koniec liturgii słowa Bożego (np. podczas wyznania wiary lub Modlitwy Powszechnej).

Wybaczmy to nieco przydługie przytoczenie przykładów potrzebnych interwencji $\mathrm{w}$ terenie. Nie chodziło $\mathrm{w}$ tych przypadkach o uleganie jurydyzmowi czy legalizmowi liturgicznemu, ale o paszanowanie uzasadnionych przepisów posoborowej liturgii.

Polski Statut Diecezjalnych Komisji Liturgicznych wymienia jeszcze cztery ważne zadania członków tych Komisji:

4. Powinni oni od czasu do czasu urządzać $w$ różnych punktach diecezji wzorcowe nabożeństwa liturgiczne. Wiadomo bowjem, że „verba docent", ale ,exempla trahunt".

5." Jest rzeczą pożądaną organizować te nabożeństwa w łączności $\mathrm{z}$ konferencją dekanalną, podczas której członek Komisji z pożytkiem wygłasza referat liturgiczny, zakończony $z$ reguły bardzo ożywioną i pożyteczną dyskusją.

14 De ... cultu mysterii Eucharistici extra Missam 1973, s. 38, nr 85.

15 IGMR nr 79 (i 269).

16 Podczas liturgii $w$ prezbiterium mogą przebywać tylko duchowni, alumni Seminariów Duchownyeh, bracia zakonni oraz ustugujący mężczyźni i chlopcy (por. IGMR nr 68, 257 i 271). 
6. Członkowie Komisji chętnie pomagają w organizowaniu także specjalnych dekanalnych konferencji liturgicznych dla kapłanów oraz w organizowaniu tygodni albo dni liturgicznych dla wiernych poszczególnych parafii.

7. I wreszcie członkowie Diecezjalnej Komisji Liturgicznej udzielają wyjaśnień w tych sprawach, które już są ujęte w przepisach liturgicznych, albo które zostały dostatecznie przedstawione w dziełach poważnych autorów.

\section{ZAKOŃCZENIE}

Przypomnienie mnóstwa „zadań Diecezjalnej Komisji ds. Liturgii w świetle dokumentów Kościoła świętego" niejednego może przerazić. Chodziło jednak o przedstawienie programu maksymalnego. Doświadczenie zaś i roztropność wskaże, jak ten program można i jak należy realizować w konkretnych okolicznościach.

Poznań

KS. ROMAN MICHAEEK

NOW OSCI

NOWOSCI

WYDAWNICTWA

POLSKIEGO TOWARZYSTWA TEOLOGICZNEGO W KRAKOWIE

Bp Jan PIETRASZKO, PO SLADACH SEOWA BOZEGO (Szkice homilii - cykl A), wydanie II. str. 226

zł 150

Ks. Waclaw SWIERZAWSKI, DYNAMICZNA PAMIĄTKA PANA str. 371

zl 180

Michal HELLER i Józef ŹYCIŃSKI, WSZECHSWIAT I FILOZOFIA (Szkice $\mathrm{z}$ filozofii i nauki)

str. 272

zl 120 